\title{
Predicting the relative sensitivity of forest produc- tion in Ireland to site quality and climate change
}

\author{
Christine L. Goodale ${ }^{1, *}$, J ohn D. A ber ${ }^{1}$, Edward P. Farrell ${ }^{2}$ \\ ${ }^{1}$ C omplex Systems Research C enter, Institute for the Study of Earth, O ceans, and Space, University of New Hampshire, \\ Durham, N ew Hampshire 03824, USA \\ ${ }^{2}$ Department of Environmental Resource Management, University College Dublin, Agriculture Building Belfield, Dublin 4, \\ Ireland
}

\begin{abstract}
M ost model-based predictions of climate change effects on forest ecosystems have used either potential or static descriptions of vegetation and site, removing the effects of direct management or land use. In this paper we use a previously developed and validated model of carbon and water balances in forest ecosystems (PnET-II) to assess the relative sensitivity of forest production in Ireland to predicted climate change and to ambient variability in site quality. After validating the model against measured productivity for 2 sets of stands, we ran the model using existing variation in site quality, represented as differences in foliar $\mathrm{N}$ concentration, and also for predicted changes in climate and atmospheric $\mathrm{CO}_{2}$. Resulting variations in productivity were compared with those due to potential errors in the specification of input parameters and to variation in current ambient climate across the region. The effects on net primary production (NPP) and wood production of either ambient variation in climate or predicted changes in temperature, precipitation and $\mathrm{CO}_{2}$ are quite small (0 to $30 \%$ ) relative to the effects of ambient variability in site quality (up to $400 \%$ ). The range of possible variation in other userspecified physiological parameters resulted in changes of less than $10 \%$ in model predictions. We conclude that site-specific conditions and management practices result in a range of forest productivity that is much greater than any likely to be induced by climate change or $\mathrm{CO}_{2}$ enrichment. We also suggest that it is essential to understand and map spatial variability in site quality, as well as to understand how the productive capacity of landscapes will change in response to management and pollution loading, if we are to predict the actual role that climate change will play in altering forest productivity and global biogeochemistry.
\end{abstract}

KEY WORDS: Regional modeling · Validation · Foliar nitrogen · Sitka spruce

\section{INTRODUCTION}

Direct disturbance by management and indirect disturbance through altered atmospheric chemistry and climate have been identified as 2 primary change agents for forest ecosystems globally (Vitousek 1994, Galloway et al. 1995). While many different ecosystem models have been used to predict the effects of changes in climate and atmospheric chemistry (e.g. VEMAP Members 1995), most use potential or static descriptions of vegetation and site so that the effects of direct management or land use on forest ecosystems have not been considered. Given this limitation, it is

\footnotetext{
*E-mail: christy.goodale@unh.edu
}

not known how direct human manipulation of the landscape can alter the predictions derived from simulations using potential or regionally averaged soil and vegetation conditions. Without this understanding, we cannot know how well current model simulations will represent actual ecosystem response. The availability of these data would allow us to examine how site characteristics or direct human manipulation influences forest productivity.

Ireland is currently experiencing a rapid change in land use through a vigorous program of reforestation, mainly with exotic conifers (Anonymous 1994). Management practices used in the establishment of plantations range from planting alone to intensive site preparation including drainage of peatlands and fertilization (Farrell 1990b, Farrell \& Boyle 1990). Extensive re- 
gional datasets are available on the soils and climate of Ireland (Gardiner \& Radford 1980, Goodale et al. 1998), and production data are also available for a large number of plantation sites (see below).

In this paper we apply a previously developed and validated model of carbon and water balances in forest ecosystems (PnET-II) and a model of climate variation in Ireland (companion article in this issue; Goodale et al. 1998) to predict the growth of coniferous forest plantations in Ireland. We use existing variation in site quality resulting from differences in soil type and management practices, represented as differences in foliar $\mathrm{N}$ concentration, in conjunction with predicted changes in climate and atmospheric $\mathrm{CO}_{2}$, to assess the relative sensitivity of these systems to site management and climatic and atmospheric change.

\section{BACKGROUND}

\subsection{History of forestry in Ireland}

Temperate deciduous forests once covered most of Ireland, but centuries of use for timber and charcoal production left the island with only $1.4 \%$ forest cover by 1905 (M cEvoy 1954, 1958). Specimen plantings of exotic conifers in the 19th century suggested the potential for very high growth rates, and reforestation initiatives, restricted initially to low-fertility soils unsuitable for agriculture, were begun early in this century. Exotic coniferous species (primarily Picea sitchensis, Pinus contorta, Picea abies, and Pinus sylvestris) were used primarily, and they currently make up $90 \%$ of Ireland's plantations (Anonymous 1994). Sitka spruce (P. sitchensis) covers over half of the forested land in Ireland (A nonymous 1994).

The early suggestions of high potential productivity have been proven correct. Ireland's average rate of potential softwood production is more than double that of France and more than triple that of Sweden and Finland (Carbonnier 1991). This, combined with changes in agricultural subsidy policies within the European Economic Community, have made forestry an increasingly attractive alternative to traditional agriculture (Conway 1991, Kearney 1991). Planting rates have accelerated rapidly over the past decade, and forests now cover $8 \%$ of the Republic of Ireland (Anonymous 1994).

M ethods used for stand establishment in Ireland differ widely depending on site conditions (Farrell 1990b). Blanket peats in the west of Ireland are generally plowed for drainage, with planting occurring on the overturned turf above the lowered water level in the furrow. The use of phosphorous fertilizers has increased with time on this site type. Minerotrophic raised bogs in the central lowlands are used as a fuel source for electricity generation. Plantation establishment on this site type has been limited to date, but may increase in the future, and generally involves planting only, without site preparation.

\subsection{M odels of forest productivity in Ireland}

Potential forest yield in Ireland (yield class, expressed in $\mathrm{m}^{3} \mathrm{ha}^{-1} \mathrm{yr}^{-1}$ ) is currently determined with empirically derived height, age, and growth relationships developed by the Forestry Commission of the United Kingdom (Edwards \& Christie 1981). This value represents expected volume production at the time of maximum mean annual increment. The British models have never been fully tested under Irish conditions, and it has been suggested that they may underestimate the growth of Sitka spruce in Ireland (Anonymous 1994). Empirical yield models also cannot be used to predict the effects of changes in environmental conditions, and in fact these models may lose reliability as environmental conditions change over time (Bossel 1991, M ohren \& Burkhart 1994, Spiecker et al. 1996). Change can result either from alterations in climatic and atmospheric conditions or from management practices that affect fertility or site quality.

\subsection{Predicted climate change}

While there is emerging scientific consensus that climates will warm over much of the Earth over the next several decades (Kattenberg et al. 1996), the degree of warming and effects on the timing and distribution of precipitation are still subject to debate. Predictions of climate change in Europe have been developed from general circulation models (GCMs) and from mesoscale models nested within GCMs, and have either included or ignored the effects of sulfate aerosols in moderating the effects of greenhouse gases. Without the aerosol correction, GCM runs presented in the most recent report of the Intergovernmental Panel on Climate Change (IPCC) suggest a 4.0 to $4.5^{\circ} \mathrm{C}$ increase in temperature across Ireland in a double $\mathrm{CO}_{2}$ environment (Kattenberg et al. 1996), and a change in precipitation of -0.3 to $+1.0 \mathrm{~mm} \mathrm{~d}^{-1}$. The nested mesoscale models, which give greater spatial specificity to predictions, suggest a 3.5 to $4.5^{\circ} \mathrm{C}$ increase in temperature, and an increase in precipitation of 0 to $1 \mathrm{~mm} \mathrm{~d}^{-1}$ (Giorgi et al. 1992, Marinucci \& Giorgi 1992).

The predicted net effect of increasing sulfate aerosols in the atmosphere is a reduction in solar radiation penetration to the Earth's surface, and a partial 
compensation for warming due to increased greenhouse gases (Mitchell et al. 1995, Trenberth et al. 1996). With the sulfate aerosol corrections included, changes in mean temperature for Ireland predicted by the Hadley Centre GCM range from +1 to $+3^{\circ} \mathrm{C}$ depending on season, while changes in precipitation are predicted to vary seasonally from -10 to $+10 \mathrm{~mm} \mathrm{mo}^{-1}$ (Mitchell et al. 1995, http://www.cru.uea.ac.uk/link/).

Global warming is expected to increase minimum temperatures more than maximum temperatures, shrinking the diurnal temperature range (Kattenberg et al. 1996, Nicholls et al. 1996). This has the important primary effect of lengthening the growing season in spring and fall and increasing nighttime respiration rates. It also has the secondary effect of reducing vapor pressure deficit (VPD) and reducing transpiration if minimum nighttime temperature is assumed to approximate the dewpoint temperature.

\subsection{Physiological effects of $\mathrm{CO}_{2}$ enrichment}

To date, most work on the direct effects of $\mathrm{CO}_{2}$ on trees has been performed in short-term studies on seedlings in $\mathrm{CO}_{2}$-enriched growth chambers. While most of these studies have demonstrated increases in photosynthesis and water use efficiency, the magnitude of change is highly variable, and many feedbacks must be quantified before scaling up in space or over time (Eamus \& J arvis 1989, Bazzaz 1990). Increases in photosynthesis may not be sustained over time due to down-regulation of photosynthesis through end product inhibition or limitations by light or nutrient levels (Bazzaz 1990). Evidence from whole ecosystems in response to $\mathrm{CO}_{2}$ enrichment suggests different responses in different systems. Northern tundra systems demonstrated no long-term direct response to $\mathrm{CO}_{2}$ enhancement (Oberbauer et al. 1986), while growth was enhanced in a nutrient-enriched estuarine marsh (Curtis et al. 1989a, b). Feedbacks between $\mathrm{CO}_{2}$ and nutrient availability are difficult to predict. Availability may be increased by enhanced photosynthesis and allocation of carbon to roots, augmenting soil exploration, or increasing allocation to mycorrhizae. However, increases in the $\mathrm{C}: \mathrm{N}$ ratio in foliage could decrease both photosynthetic rate (Reich et al. 1995) and nutrient mineralization (Bazzaz 1990).

Water use efficiency has consistently been shown to increase in a doubled- $\mathrm{CO}_{2}$ environment, although the magnitude of increase can vary from 20 to $160 \%$ (Eamus \& J arvis 1989, Woodward et al. 1991, Polley et al. 1993, Pitelka 1994). Water use efficiency may increase due to increased photosynthesis and/or reduced stomatal conductance. In Sitka spruce seedlings, doubling $\mathrm{CO}_{2}$ concentration caused water use efficiency to double (Townend 1993).

\section{METHODS}

\subsection{Model structure}

PnET-II (Fig. 1) is one of a number of published, physiologically based models designed to predict forest growth through calculations of processes such as photosynthesis and transpiration (e.g. Pastor \& Post 1986, Running \& Coughlan 1988, Raich et al. 1991, McM urtrie et al. 1992). While more complex than the empirically based models currently in use in Ireland, physiological models offer the potential to capture and predict more accurately the effects of changes in climate and site quality. PnET-II differs from many models in that input parameters are determined directly from the literature with no attempt to calibrate the inputs to achieve measured outputs. Data on predicted variables [e.g. net primary production (NPP), wood production, transpiration, water yield] are not used in

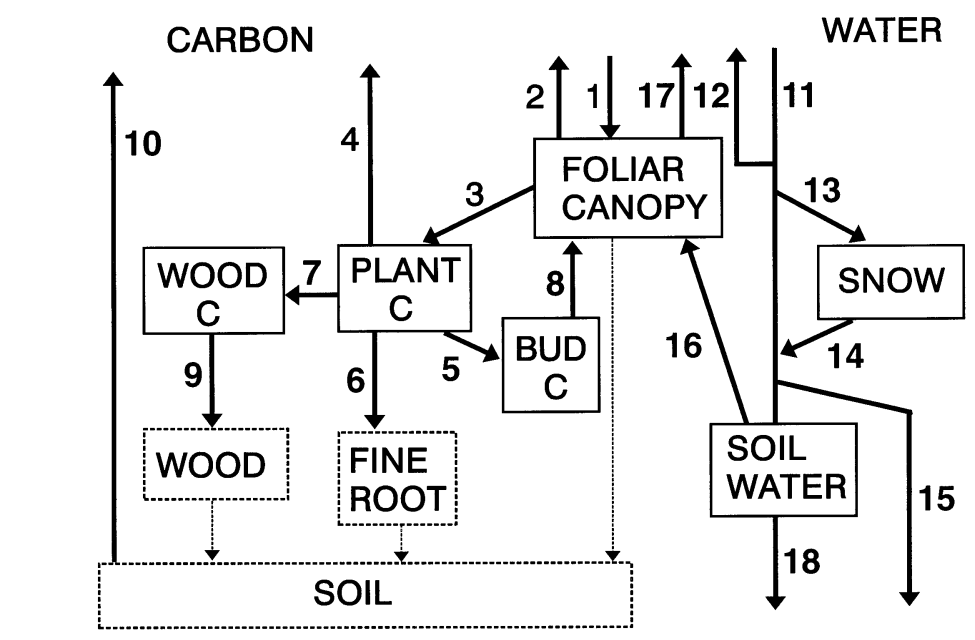

1. Gross Photosynthesis
2. Foliar Respiration
3. Transfer to Mobile C
4. Growth and Maintenance
Respiration
PnET Fluxes

5. Allocation to Buds

6. Allocation to Fine Roots

7. Allocation to Wood Carbon

8. Foliar Production

9. Wood Production

10. Soil Respiration
11. Precipitation

12. Interception

13. Snow / Rain Partition

14. Snowmelt

15. Fast Flow

16. Uptake

17. Transpiration

18. Drainage

Fig. 1. Structural diagram of the PnET-II model (A ber et al. 1995). PnET-II does not explicitly track accumulation or litter production of wood and roots (dashed boxes) 
any way to determine the inputs. This lack of calibration allows the model to be tested against the independent output variables listed above to assess the accuracy of model function.

PnET-II was designed to predict monthly carbon and water balances using relatively few inputs, so that it can be run within the data constraints of a geographic information system (GIS). Required site variables include vegetation type, plant-available soil water holding capacity (WHC), and average monthly climate data (maximum and minimum temperature, precipitation, and solar radiation). The original PnET (A ber \& Federer 1992) was validated against measured data from 10 widely distributed temperate and boreal forest

Table 1. Input parameters required by the PnET-II model. Starred values $(*)$ vary with vegetation type and are listed in Table 2

\begin{tabular}{|c|c|c|}
\hline Name & Definition and units & Value \\
\hline \multicolumn{3}{|l|}{ Canopy variables } \\
\hline $\mathrm{k}$ & Canopy light attenuation constant (no units) & * \\
\hline FolNCon & Foliar nitrogen content $\left(g_{N} g_{\text {leaf }}^{-1}\right)$ & * \\
\hline FolReten & Foliage retention time (yr) & * \\
\hline SLWMax & Specific leaf weight at top of canopy $\left(\mathrm{g} \mathrm{m}^{-2}\right)$ & $*$ \\
\hline SLWDel & Change in SLW with increasing foliar mass above leaf layer $\left(\mathrm{g} \mathrm{m}^{-2} \mathrm{~g}^{-1}\right)$ & $*$ \\
\hline GDDFolStart & Growing degree days at which foliar production begins & $*$ \\
\hline GDDFolEnd & Growing degree days at which foliar production ends & $*$ \\
\hline GDDWoodStart & Growing degree days at which wood production begins & $*$ \\
\hline GDDWoodEnd & Growing degree days at which wood production ends & $*$ \\
\hline FolRelGrowMax & Maximum relative growth rate for foliage $\left(\mathrm{yr}^{-1}\right)$ & 0.3 \\
\hline \multicolumn{3}{|c|}{ Photosynthesis variables } \\
\hline AmaxA & $\begin{array}{l}\text { Intercept of the relationship between foliar } \mathrm{N} \% \text { and max. photosynthesis } \\
\text { rate }\left(\mathrm{nmol} \mathrm{CO}_{2} \mathrm{gleaf}^{-1} \mathrm{~s}^{-1}\right)\end{array}$ & $*$ \\
\hline AmaxB & $\begin{array}{l}\text { Slope of the relationship between foliar } \mathrm{N} \% \text { and max. photosynthesis } \\
\text { rate }\left(\mathrm{nmol} \mathrm{CO} \mathrm{CO}_{2} \mathrm{gleaf}^{-1} \mathrm{~s}^{-1}\right)\end{array}$ & $*$ \\
\hline BaseFolRespFrac & Respiration as a fraction of maximum photosynthesis & 0.1 \\
\hline HalfSat & Half saturation light level (mmol PAR $\left.\mathrm{m}^{-2} \mathrm{~s}^{-1}\right)$ & 200 \\
\hline AmaxFrac & Daily A max as a fraction of early morning instantaneous rate & 0.76 \\
\hline PsnTOpt & Optimum temperature for photosynthesis $\left({ }^{\circ} \mathrm{C}\right)$ & $*$ \\
\hline PsnTM in & Minimum temperature for photosynthesis $\left({ }^{\circ} \mathrm{C}\right)$ & $*$ \\
\hline RespQ10 & $\begin{array}{l}\mathrm{Q}_{10} \text { value for foliar respiration (factor of respiration increase per } \\
10^{\circ} \mathrm{C} \text { temperature change) }\end{array}$ & 2.0 \\
\hline \multicolumn{3}{|c|}{ Water balance variables } \\
\hline DVPDA & Coefficients for determining DVPD, a photosynthesis multiplier & $*$ \\
\hline DVPDB & ranging from 0 to $1 . \mathrm{DVPD}=1-\mathrm{DVPDA} \times \mathrm{VPD}$ DVPDB & $*$ \\
\hline PreclntFrac & Fraction of precipitation intercepted and evaporated & $*$ \\
\hline WUEConst & $\begin{array}{l}\text { Constant in the equation for water use efficiency (WUE) as a function of } \\
\text { vapor pressure deficit (VPD): WUEConst }\left(\mathrm{mg}_{\mathrm{CO}_{2}} \mathrm{~g}^{-1} \mathrm{H}_{2} \mathrm{O} \mathrm{kPa}\right)=\text { WUE } \times \text { VPD }\end{array}$ & 10.9 \\
\hline FastFlowFrac & Fraction of water inputs lost directly to drainage & 0.1 \\
\hline f & Soil water release parameter $\left(\mathrm{d}^{-1}\right)$ & 0.04 \\
\hline \multicolumn{3}{|c|}{ Carbon allocation variables } \\
\hline CFracBiomass & Carbon as a fraction of foliage mass & 0.45 \\
\hline RootAllocA & Intercept of the relationship between foliar and root allocation & 0 \\
\hline RootAllocB & Slope of the relationship between foliar and root allocation & 2 \\
\hline GRespFrac & Growth respiration, as a fraction of allocation & 0.25 \\
\hline RootM RespFrac & Ratio of fine root maintenance respiration to biomass production & 1 \\
\hline WoodM RespA & Wood maintenance respiration as a fraction of gross photosynthesis & 0.07 \\
\hline PlantCReserveFrac & Fraction of plant $\mathrm{C}$ held in reserve after allocation to bud $\mathrm{C}$ & 0.75 \\
\hline MinWoodFolRatio & Minimum ratio of carbon allocation to wood and foliage & $*$ \\
\hline \multicolumn{3}{|c|}{ Soil respiration variables } \\
\hline SoilRespA & $\begin{array}{l}\text { Intercept of relationship between mean monthly temperature }\left({ }^{\circ} \mathrm{C}\right) \text { and } \\
\text { soil respiration }\left(\mathrm{g}_{\mathrm{c}} \mathrm{m}^{-2} \mathrm{mo}^{-1}\right)\end{array}$ & 27.46 \\
\hline SoilRespB & $\begin{array}{l}\text { Slope of relationship between mean monthly temperature }\left({ }^{\circ} \mathrm{C}\right) \text { and } \\
\text { soil respiration }\left(\mathrm{g}_{\mathrm{c}} \mathrm{m}^{-2} \mathrm{mo}^{-1}\right)\end{array}$ & 0.06844 \\
\hline \multicolumn{3}{|c|}{ Wood yield conversion variables } \\
\hline BoleFrac & Bolewood as a percent of total woody NPP & $*$ \\
\hline Density & Wood density $\left(\mathrm{g} \mathrm{cm}^{-3}\right)$ & $*$ \\
\hline
\end{tabular}


ecosystems. PnET-II (A ber et al. 1995) contains a revised photosynthetic routine which has been validated against daily whole-canopy $\mathrm{CO}_{2}$ exchange data from eddy-correlation measurements from the Harvard Forest, Petersham, M assachusetts, USA (Aber et al. 1996) and improved plant allocation and soil respiration terms.

The core relationship in PnET is the linear correlation between maximum photosynthesis and foliar nitrogen content observed across and within many plant species (Field \& M ooney 1986, M itchell \& Hinckley 1993, Reich et al. 1995). PnET-II uses this relationship to predict maximum photosynthesis for a specified foliar N concentration. Sub-optimal conditions of temperature, light, humidity, or water availability determine realized net photosynthesis. The model simulates whole-canopy photosynthesis by combining estimates of potential net photosynthesis with a photosynthetic light response curve and an equation for light attenuation through the canopy. Potential photosynthesis determines transpirational demand, which is fulfilled as long as sufficient soil water exists. Respiration, growth, and carbon allocation terms determine partitioning of photosynthate to roots, foliage, and buds. Wood production is derived from the carbon left over after allocation to all other carbon pools, including stored reserves (see Aber et al. 1995 for complete model description).

Two additional terms (BoleFrac and Density) were added to PnET-II to convert the units of estimated wood production from weight of all woody material $\left(\mathrm{g} \mathrm{m}^{-2} \mathrm{yr}^{-1}\right)$ to volume increment of bolewood $\left(\mathrm{m}^{3} \mathrm{ha}^{-1} \mathrm{yr}^{-1}\right)$. The added terms did not affect calculations of physiological processes, but allowed comparison of predictions between PnET-II and the existing empirical yield models.

\subsection{Model parameterization}

Three types of parameters are required to run PnET-II (Table 1): (1) physiological parameters that are held constant for all forest types; (2) physiological parameters that vary with vegetation type (Table 2); and (3) site-specific parameters that vary with location, such as climate, soil WHC, and elevation. Values for parameters held constant for all vegetation types are described in Aber et al. (1995, 1996). Parameter values spe- cific to the simulations reported here were not calibrated, but determined from literature review of published measurements of Sitka spruce physiology and physical properties. If published data sources could not be found for sites in Ireland or Northern Ireland, reports were sought for sites in Scotland, England, or Wales. This selection procedure made the parameters as site-specific as possible but should not be confused with calibration, which involves choosing sets of input parameter values which optimize fits of predicted values with measured data. Non-calibrated models require that careful attention be paid to determining parameter values, so we describe this process in detail here.

A maxA, A maxB, MinWoodfolRatio. Of the parameters that change with vegetation type (Table 2 ), AmaxA, AmaxB, and M inWoodFolRatio are held constant within the general vegetation types of broadleaf deciduous or evergreen coniferous. AmaxA and AmaxB describe the intercept and slope, respectively, of the relationship between potential photosynthesis (Amax; nmol $\mathrm{CO}_{2} \mathrm{~g}_{\text {leaf }}{ }^{-1} \mathrm{~s}^{-1}$ ) and foliar $\mathrm{N}$ (\% dry weight). One photosynthesis/foliar $\mathrm{N}$ relationship is used to for needle-leaved evergreen species, and a steeper one is used for broad-leaved deciduous species (Reich et al. 1995, A ber et al. 1996). MinWoodFolRatio is the lowest ratio of wood production to foliar production allowed, representing the minimum

Table 2. List of values for PnET-II variables that vary with vegetation type (starred values in Table 1). A ber et al. (1996) describes the data sources for hardwoods, pine, and red spruce/balsam fir values. The Douglas-fir parameters are from a previous version of PnET (Aber \& Federer 1992) which had slightly different parameter requirements. Data sources for Sitka spruce values are described in this paper

\begin{tabular}{|c|c|c|c|c|c|}
\hline Parameter & Hardwoods & Pine & $\begin{array}{c}\text { Red spruce, } \\
\text { balsam fir }\end{array}$ & $\begin{array}{c}\text { Douglas- } \\
\mathrm{fir}\end{array}$ & $\begin{array}{l}\text { Sitka } \\
\text { spruce }\end{array}$ \\
\hline AmaxA & -46.0 & 5.3 & 5.3 & & 5.3 \\
\hline AmaxB & 71.9 & 21.5 & 21.5 & & 21.5 \\
\hline MinWoodFolRatio & 1.5 & 1.25 & 1.25 & & 1.25 \\
\hline FolNCon & $2.4,1.9$ & 1.2 & 0.8 & & 1.8 \\
\hline $\mathrm{k}$ & 0.58 & 0.5 & 0.5 & 0.4 & 0.5 \\
\hline SLWMax & 100 & 200 & 170 & 135 & 275 \\
\hline SLWDel & 0.2 & 0.2 & 0 & 0 & 0.06 \\
\hline FolReten & 1 & 2.25 & 4 & 4.5 & 2.6 \\
\hline PsnTM in & 4 & 4 & 0 & 0 & 0 \\
\hline PsnTOpt & 24 & 24 & 20 & 20 & 19 \\
\hline DVPDA & 0.05 & 0.05 & 0.05 & 0.21 & 0.21 \\
\hline DVPDB & 2 & 2 & 2 & 1 & 1 \\
\hline PreclntFrac & 0.11 & 0.15 & 0.15 & 0.15 & 0.30 \\
\hline GDDFolStart & 100 & 900 & 300 & & 650 \\
\hline GDDFolEnd & 900 & 1600 & 1400 & & 1500 \\
\hline GDDWoodStart & 900 & 900 & 300 & & 650 \\
\hline GDDWoodEnd & 1600 & 1600 & 1400 & & 1500 \\
\hline BoleFrac & & & & & 0.64 \\
\hline Density & & & & & 0.34 \\
\hline
\end{tabular}


investment in new xylem tissue to support new foliar production.

Foliar nitrogen content (FolN Con). FolNCon is the canopy-averaged percent of nitrogen in dry foliage $\left(\mathrm{g}_{\mathrm{N}} \mathrm{g}_{\mathrm{leaf}}{ }^{-1}\right)$. Foliar $\mathrm{N}$ may vary within a stand due to needle age (Hom \& Oechel 1983) or canopy position (Brooks et al. 1994). These differences should be integrated to obtain a value for the whole canopy.

Foliar nitrogen values varied dramatically in the managed Sitka spruce plantations of Ireland and the United Kingdom (Table 3), most likely due to the wide range of site types and treatments of the Sitka plantations. Several of these sites were studied specifically because they were nitrogen deficient (poorly aerated peatlands or peaty sites with strong Calluna vulgaris competition for $\mathrm{N}$ ), while the higher foliar $\mathrm{N}$ values were the result of site treatment (fertilization or aeration).

Foliar nitrogen values are particularly variable on peatland sites, where $\mathrm{N}$ availability is strongly affected by fertilization (Farrell 1985, 1990a) and drainage (Schaible \& Dickson 1990). Deficiencies of both $\mathrm{P}$ and $\mathrm{N}$ limit the growth of Sitka spruce on blanket peats in western Ireland (Farrell 1985, 1990a). Data from sites in the U.S. and the tropics indicate that the relationship between foliar nitrogen and pho- tosynthesis weakens when phosphorus is limiting (Reich \& Schoettle 1988, Reich et al. 1994). Phosphorus deficiency inhibits efficient use of nitrogen by white pine (Pinus strobus) at P:N ratios below 0.10 to 0.14 (Reich \& Schoettle 1988). As the P:N ratios for many of the Sitka spruce sites are also in this range (Table 3), productivity at these sites may be limited by phosphorus availability.

PnET-II should be run using site-level, canopy-averaged foliar $\mathrm{N}$ data where these measurements exist. Where foliar $\mathrm{N}$ measurements were not available, a default value of $1.8 \%$ was used. This value was the median foliar $\mathrm{N}$ concentration of 3 years' worth of regional surveys of current-year foliar chemistry throughout Ireland (McCarthy 1993). We expect this measure to over-represent FolN Con for 2 reasons: first, the average foliar $\mathrm{N}$ content of the whole canopy is generally slightly lower than that of the current year foliage; and, second, most Sitka spruce stands in Ireland are fairly young, so reported foliar $\mathrm{N}$ concentrations may be somewhat higher than if the stands were mature. The magnitudes of these biases are not known.

Canopy light attenuation ( $k$ ). The canopy light attenuation constant, $k$, describes the decrease in light levels with canopy depth according to the equation:

Table 3. Reported foliar nitrogen contents $\left(g_{N} g_{d r y}\right.$ foliage $\left.{ }^{-1}\right)$ and foliar P:N ratios from Sitka spruce plantations in Ireland and the United Kingdom

\begin{tabular}{|c|c|c|c|c|c|}
\hline Foliar \% N & $\mathrm{P}: \mathrm{N}$ ratio & $\begin{array}{l}\text { Stand age } \\
\quad(y r)\end{array}$ & Soil type & Site & Source \\
\hline $\begin{array}{l}1.8 \\
2.1 \\
1.5\end{array}$ & $\begin{array}{l}0.10 \\
0.09 \\
0.10\end{array}$ & Varied & Varied & $\begin{array}{l}\text { M ean of at least one sample from each of } \\
25 \text { plots in Ireland for 1988, 1989, and 1990, } \\
\text { respectively }\end{array}$ & McCarthy (1993) \\
\hline $\begin{array}{l}1.6 \\
1.3\end{array}$ & $\begin{array}{l}0.12 \\
0.23\end{array}$ & $\begin{array}{l}35 \\
36\end{array}$ & Peat & $\begin{array}{l}1991 \text { and } 1992 \text { measurements at Cloosh } \\
\text { Forest, Co. Galway, Ireland }\end{array}$ & $\begin{array}{l}\text { Farrell et al. } \\
\text { (1994) }\end{array}$ \\
\hline $\begin{array}{l}1.9 \\
1.6\end{array}$ & $\begin{array}{l}0.11 \\
0.10\end{array}$ & $\begin{array}{l}32 \\
33\end{array}$ & Podzol & $\begin{array}{l}1991 \text { and } 1992 \text { measurements at Roundwood } \\
\text { Forest, Co. Wicklow, Ireland }\end{array}$ & $\begin{array}{l}\text { Farrell et al. } \\
\text { (1994) }\end{array}$ \\
\hline 1.8 & 0.07 & 30 & Peat/gley & M ean of 8 trees; Co. Wicklow, Ireland & $\begin{array}{l}\text { Carey \& O’Brien } \\
\text { (1979) }\end{array}$ \\
\hline $\begin{array}{l}1.0 \\
1.2 \\
1.3 \\
1.6\end{array}$ & $\begin{array}{l}0.12 \\
0.11 \\
0.11 \\
0.10\end{array}$ & 17 & Peat & $\begin{array}{l}\text { Study on effects of peat drainage patterns on } \\
\text { forest growth; Cam Forest, N orthern Ireland }\end{array}$ & $\begin{array}{l}\text { Schaible \& } \\
\text { Dickson (1990) }\end{array}$ \\
\hline $1.1-1.5$ & $0.10-0.21$ & & $\begin{array}{l}\text { Blanket } \\
\text { peat }\end{array}$ & $\begin{array}{l}\text { Seven years of measurements averaged over } \\
\text { plots subject to varied N and P fertilizer } \\
\text { treatments; Glenamoy, Co. M ayo, Ireland }\end{array}$ & Farrell (1990a) \\
\hline $\begin{array}{l}0.6 \\
0.8 \\
1.2 \\
1.2\end{array}$ & $\begin{array}{l}0.14 \\
0.14 \\
0.10 \\
0.09\end{array}$ & $\begin{array}{l}12 \\
19 \\
32 \\
50\end{array}$ & Peat/gley & $\begin{array}{l}\text { Culloden, Inverness, Scotland } \\
\text { Inchnacardoch, Fort Augustus, Scotland } \\
\text { M ean of } 6 \text { sites across Scotland } \\
\text { Kirkten Glen, Scotland }\end{array}$ & $\begin{array}{l}\text { Miller et al. } \\
\text { (1993) }\end{array}$ \\
\hline
\end{tabular}




$$
\mathrm{I}_{\mathrm{i}}=\mathrm{I}_{0} \mathrm{e}^{-\mathrm{k}\left(\mathrm{LAl} \mathrm{I}_{\mathrm{i}}\right)}
$$

where $I_{i}$ is the solar radiation received at level $i$ in the canopy, $I_{0}$ is radiation at the top of the canopy, and $L A I_{i}$ is the total leaf area index $\left(\mathrm{m}^{2} \mathrm{~m}^{-2}\right)$ above canopy layer i. Measurements of $k$ for Sitka spruce in Scotland range from 0.43 to 0.58 (Norman \& J arvis 1972, J arvis et al. 1976, J arvis 1981, J arvis \& Leverenz 1983), with a median value of 0.5. PnET-II used a value of 0.5 for $k$ for Sitka spruce. This is the same $k$ value determined for several other conifers native to the northwestern United States (Pierce \& Running 1988, Pierce et al. 1994).

Specific leaf weight (SLWMax and SLWDel). Sun leaves at the top of the canopy usually have a greater specific leaf weight $\left(\mathrm{g} \mathrm{m}^{-2}\right)$ than shade leaves at the bottom. SLWM ax represents the maximum foliar specific weight at the top of the canopy $\left(\mathrm{g} \mathrm{m}^{-2}\right)$, and SLWDel $\left(\mathrm{g} \mathrm{m}^{-2} \mathrm{~g}^{-1}\right)$ represents the change in foliar specific weight with canopy depth, where canopy depth is the foliar mass above a given layer $\left(\mathrm{g}_{\text {leaf }} \mathrm{m}_{\text {ground }}{ }^{-2}\right)$.

Foliar specific leaf weight data from two 16- to 20-yrold Sitka spruce stands in Scotland were used to calculate SLWDel values of 0.063 (Norman \& J arvis 1972) and $0.056 \mathrm{~g} \mathrm{~m}^{-2} \mathrm{~g}^{-1}$ (Ford 1982), and so SLWDel was set at $0.06 \mathrm{~g} \mathrm{~m}^{-2} \mathrm{~g}^{-1}$ for Sitka spruce. M aximum foliar specific weights in the Scottish stands were approximately $260 \mathrm{~g} \mathrm{~m}^{-2}$ (Norman \& J arvis 1972) and $290 \mathrm{~g} \mathrm{~m}^{-2}$ (Ford 1982). SLWM ax was set at $275 \mathrm{~g} \mathrm{~m}^{-2}$.

Length of foliar retention (FolReten). FolReten represents the mean number of years that trees retain their foliage. At the end of each growing season, PnETII 'drops' 1/FolReten of the calculated foliar mass. While Sitka spruce can retain some of its foliage for 4 or more years (N orman \& J arvis 1972, Watts et al. 1976, Harcombe et al. 1990), only a small portion of Sitka spruce foliage reaches this age (N orman \& J arvis 1972, Watts et al. 1976). M easurements of the abundance of foliage in different age classes in 20- to 25-yr-old Sitka spruce in Scotland (Norman \& J arvis 1972, Watts et al. 1976) indicate that Sitka spruce drops 38 to $39 \%$ of its foliage per year, resulting in an average foliar retention time of $2.6 \mathrm{yr}$. This value ignores any changes in foliar retention time brought about by pest attacks (e.g. spruce aphid).

Temperature controls (PsnTMin and PsnTopt). PsnTM in and PsnTOpt are, respectively, the minimum and the optimum daytime temperatures for photosynthesis. PnET-II uses these 2 parameters to describe a parabolic response of photosynthesis to temperature. Although detached Sitka spruce shoots have demonstrated low levels of instantaneous photosynthesis at -5 to $-6^{\circ} \mathrm{C}$ (Ludlow $\&$ J arvis 1971, N eilson et al. 1972), significant photosynthesis is unlikely to occur during months with mean daytime temperatures of -5 to $-6^{\circ} \mathrm{C}$, when much colder minimum temperatures adversely affect photosynthesis. PsnTMin was set at $0^{\circ} \mathrm{C}$.

Optimum temperatures for photosynthesis in Sitka spruce can vary from 10 to $22^{\circ} \mathrm{C}$, depending on provenance and time of year (Ludlow \& J arvis 1971, N eilson et al. 1972), but the most common optimum temperature for Sitka spruce is $19^{\circ} \mathrm{C}$ (Neilson et al. 1972), so PsnTOpt was set at $19^{\circ} \mathrm{C}$.

Humidity controls (DVPDA and DVPDB). The coastal Pacific Northwest region of the United States and $\mathrm{C}$ anada - the natural range of Sitka spruce-experiences mild wet winters and warm dry summers. Tree species native to this region have evolved to close their stomata in response to both soil drought and high vapor pressure deficit (Running 1976, Waring \& Franklin 1979). DVPDA and DVPDB are empiricallyderived coefficients that describe the effect of vapor pressure deficit (VPD, kPa) on photosynthesis. PnET-II calculates the effect of VPD on photosynthesis by multiplying potential photosynthesis by DVPD, a scalar ranging from 0 to 1 , which is calculated as:

$$
\text { DVPD }=1-\text { DVPDA } \times \text { VPD DVPDB }
$$

Estimates of DVPD were derived from measurements of the effects of VPD on photosynthesis in wellwatered Sitka spruce seedlings (Watts \& Neilson 1978, Sandford \& Jarvis 1986). Maximum photosynthesis was assumed to occur at the lowest VPD treatment, and subsequent increases in VPD were presumed to be the only cause of decreased photosynthesis (Fig. 2). Regression coefficients derived from the Sandford \& $J$ arvis (1986) data (DVPD $=1.00-0.21 \mathrm{VPD} ; \mathrm{R}^{2}=0.99$, $p<0.001$ ) exactly matched the linear VPD effect previously determined for Douglas-fir and lodgepole pine (Table 2), and so DVPDA and DVPDB were set to these values.

Interception of precipitation (PreclntFrac). PreclntFrac represents the percent of monthly precipitation intercepted by the canopy. Rainfall interception in Ireland and the United Kingdom ranges from 25 to $49 \%$ of total annual rainfall (Table 4). Although the oldest plantation has the highest interception value, no other trend between interception and age was apparent. PrecIntFrac was assigned a value of $30 \%$, the median of the interception fractions listed in Table 4. Measured rainfall interception values for Sitka spruce were substantially higher than for the other vegetation types that PnET-II has considered (Table 2).

Growing degree days (GDDFolStart, GDDFolEnd, G DDWoodStart, GDDWoodEnd). GDDFolStart, GDDFolEnd, GDDWoodStart and GDDWoodEnd are growing-degree-day controls on the start and end of foliage and wood production. PnET-II calculates growing 


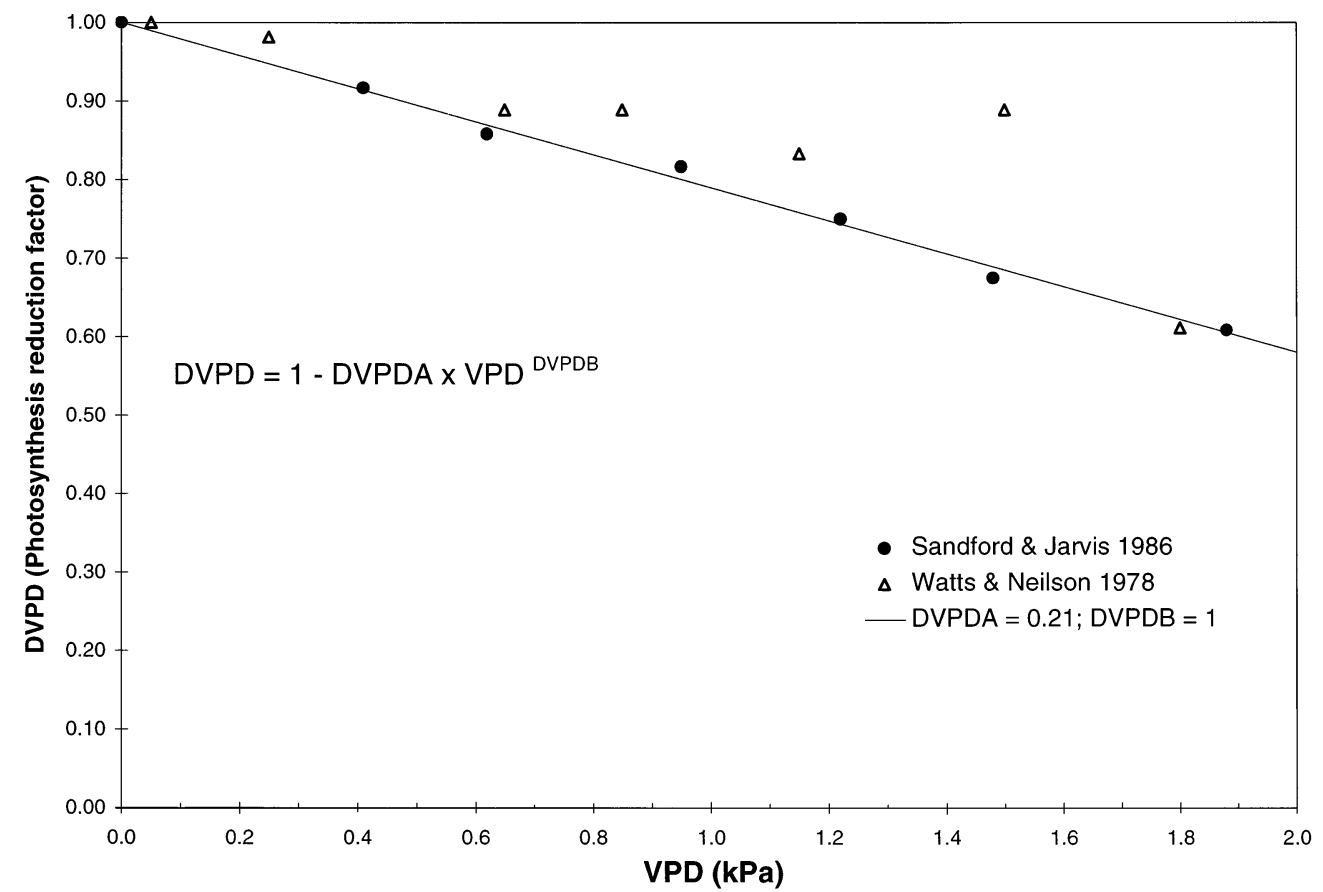

Fig. 2. Effect of vapor pressure deficit (VPD) on DVPD, a photosynthesis reduction factor. VPD effects on photosynthesis are estimated by multiplying potential photosynthesis by DVPD degree days as the accumulated mean temperature above $0^{\circ} \mathrm{C}$ from J anuary 1 . The timing of wood production (GDDWoodStart and GDDWoodEnd) is assumed to correspond with the timing of foliage production (GDDFolStart and GDDFolEnd).

Table 4. Reported canopy interception as a fraction of total annual rainfall from Sitka spruce plantations in Ireland and the United Kingdom

\begin{tabular}{|c|c|c|c|}
\hline $\begin{array}{l}\text { Interception } \\
(\%)\end{array}$ & $\begin{array}{l}\text { Stand age } \\
\quad(y r)\end{array}$ & Site location & Source \\
\hline 47 & 20 & $\begin{array}{l}\text { Glenturk, Co. Mayo, } \\
\text { western Ireland }\end{array}$ & Farrell (1990a) \\
\hline 38 & 33 & $\begin{array}{l}\text { Roundwood Forest, } \\
\text { Co. Wicklow, } \\
\text { eastern Ireland }\end{array}$ & Farrell et al. (1994) \\
\hline 22 & 36 & $\begin{array}{l}\text { Cloosh Forest, Co. M ayo, } \\
\text { western Ireland }\end{array}$ & Farrell et al. (1994) \\
\hline 30 & 14 & $\begin{array}{l}\text { Rivox, Greskine Forest, } \\
\text { Dumfriesshire, } \\
\text { southern Scotland }\end{array}$ & $\begin{array}{l}\text { Ford \& Deans } \\
\text { (1978) }\end{array}$ \\
\hline $\begin{array}{l}29 \\
49\end{array}$ & $\begin{array}{l}25 \\
63\end{array}$ & $\begin{array}{l}\text { Kielder Forest, } \\
\text { N orthumberland }\end{array}$ & $\begin{array}{l}\text { Anderson \& Pyatt } \\
\text { (1986), from } \\
\text { J ohnson (1990) }\end{array}$ \\
\hline 25 & 29 & Plynlimon, United Kingdom & $\begin{array}{l}\text { Hudson (1988), } \\
\text { from J ohnson } \\
(1990)\end{array}$ \\
\hline 28 & 50 & $\begin{array}{l}\text { Kirkten Glen, } \\
\text { Highland Scotland }\end{array}$ & J ohnson (1990) \\
\hline 33 & 18 & $\begin{array}{l}\text { Cloich, Glentress Forest, } \\
\text { southeastern Scotland }\end{array}$ & $\begin{array}{l}\text { Teklehaimanot } \\
\text { et al. (1991) }\end{array}$ \\
\hline
\end{tabular}

Bud burst in Sitka spruce has been shown to correspond with degree days above $5^{\circ} \mathrm{C}$ accumulated after February 1 and the number of chilling days less than $5^{\circ} \mathrm{C}$ after November 1 (Cannell \& Smith 1983). Estimates of GDDFolStart were approximated from these data, and ranged from 600 to 750 with an average of 650 .

Dates of Sitka spruce bud and shoot elongation have been reported for sites in Argyll, Scotland (Cannell \& Willett 1975) and M offat Forest, Scotland (Ford et al. 1987). Both studies report temperatures only for the growing season. J anuary to May growing degree days were approximated from long-term (1941 to 1970) average temperature measurements at weather stations in western Scotland. Estimates of GDDFolStart at the 2 sites were 700 to 750, and GDDFolEnd was 1400 to 1600 . For all Sitka spruce model runs, GDDFolStart and GDDWoodStart were set to 650; GDDFolEnd and GDDWoodEnd, to 1500.

Wood production conversion factors (BoleFrac and Density). BoleFrac and Density were added to PnET-II to convert wood production estimates from woody NPP ( $g_{\text {biomass }} \mathrm{m}^{-2} \mathrm{yr}^{-1}$ ) to stem volume increment $\left(\mathrm{m}^{3} \mathrm{ha}^{-1} \mathrm{yr}^{-1}\right)$. BoleFrac represents the fraction of all 
Table 5. Estimates of BoleFrac for Sitka spruce and other coniferous species. BoleFrac represents the fraction of all woody net primary production (branches, woody roots, bolewood, bark) allocated to stemwood and bark, and may be represented by allocation patterns of woody biomass

\begin{tabular}{|c|c|c|c|c|}
\hline Species & BoleFrac & $\begin{array}{c}\text { Stand age } \\
(y r)\end{array}$ & Site location & Source \\
\hline Picea sitchensis & $69 \%, N P P$ & 18 & Scotland & Ford (1982) \\
\hline Pinus nigra var. maritima & $60 \%, N P P$ & 36 & Scotland & Miller \& Miller (1976) \\
\hline Abies amabilis & $\begin{array}{l}51 \%, \text { NPP } \\
64 \%, \text { NPP }\end{array}$ & $\begin{array}{c}23 \\
180\end{array}$ & Oregon, USA & Grier et al. (1981) \\
\hline $\begin{array}{l}\text { Pseudotsuga menziesii } \\
\text { Tsuga heterophylla } \\
\text { Thuja plicta }\end{array}$ & $\begin{array}{l}78 \%, \text { NPP, biomass } \\
57 \%, \text { NPP, biomass } \\
52 \%, \text { NPP, biomass }\end{array}$ & $\begin{array}{l}\text { Old } \\
\text { growth } \\
(-450)\end{array}$ & Oregon, USA & Grier \& Logan (1977) \\
\hline Picea sitchensis & $64 \%$, biomass & 30 & Co. Wicklow, Ireland & Carey \& O’Brien (1979) \\
\hline
\end{tabular}

woody NPP (woody roots, bark, branches, and bolewood) allocated to bolewood and stem bark.

Measurements from a highly productive Sitka spruce stand indicate that $69 \%$ of total woody NPP is allocated to bolewood (Ford 1982). No other NPP data were found for Sitka spruce, but patterns of NPP allocation in other conifers and biomass allocation in Sitka spruce suggest that the high-productivity stand allocates a rather large percentage of woody NPP to the stem (Table 5). Data for several western U.S. conifers indicate that woody NPP and biomass allocation patterns were essentially identical (Grier \& Logan 1977), and so PnET-II used the more conservative estimate of bolewood allocation derived from biomass allocation patterns observed by Carey \& O'Brien (1979), and BoleFrac was assigned a value of 0.64 .

Density is the density of bolewood $\left(\mathrm{g} \mathrm{cm}^{-3}\right)$ used to convert from stem weight to volume. Most reported estimates of Sitka spruce density were between 0.3 and $0.4 \mathrm{~g} \mathrm{~cm}^{-3}$ (Gholz 1982, J arvis \& Leverenz 1983, Harcombe et al. 1990, Dewar \& Cannell 1992). Young Sitka spruce can have densities up to $0.6 \mathrm{~g} \mathrm{~cm}^{-3}$, but wood density decreases with age (Cannell et al. 1983). According to UK forest mensuration charts, density varies inversely with growth rate (Hamilton 1985, from Dewar \& Cannell 1992). A density of $0.34 \mathrm{~g} \mathrm{~cm}^{-3}$ was used to correspond with Ireland's mean yield class of $16 \mathrm{~m}^{3} \mathrm{ha}^{-1} \mathrm{yr}^{-1}$ (Carbonnier 1991, A nonymous 1994).

Climate and soils data. To validate PnET-II against measured forest production values, and to perform sensitivity analyses appropriate for the range of conditions in Ireland, we needed site-level data on climate and soil WHC for those sites where production data were available. Climate data (average monthly maximum and minimum temperature, precipitation and radiation) were derived from a statistical model developed for Ireland to describe the spatial and elevational variation of average monthly climate for the period
1951 to 1980 (Goodale et al. 1998). Sites were located within a $1 \mathrm{~km}$ resolution GIS based on a digital elevation model (DEM) of the same scale developed for this project, and climate data obtained using the spatial model.

In order to estimate plant-available soil WHC, the 1:575000 General Soil Map of Ireland (Gardiner \& Radford 1980) was digitized and converted to a raster system with $1 \mathrm{~km}^{2}$ grid cells to overlay the DEM described above (Fig. 3). Each of the map's 44 soil associations was assigned an estimated WHC value (J.

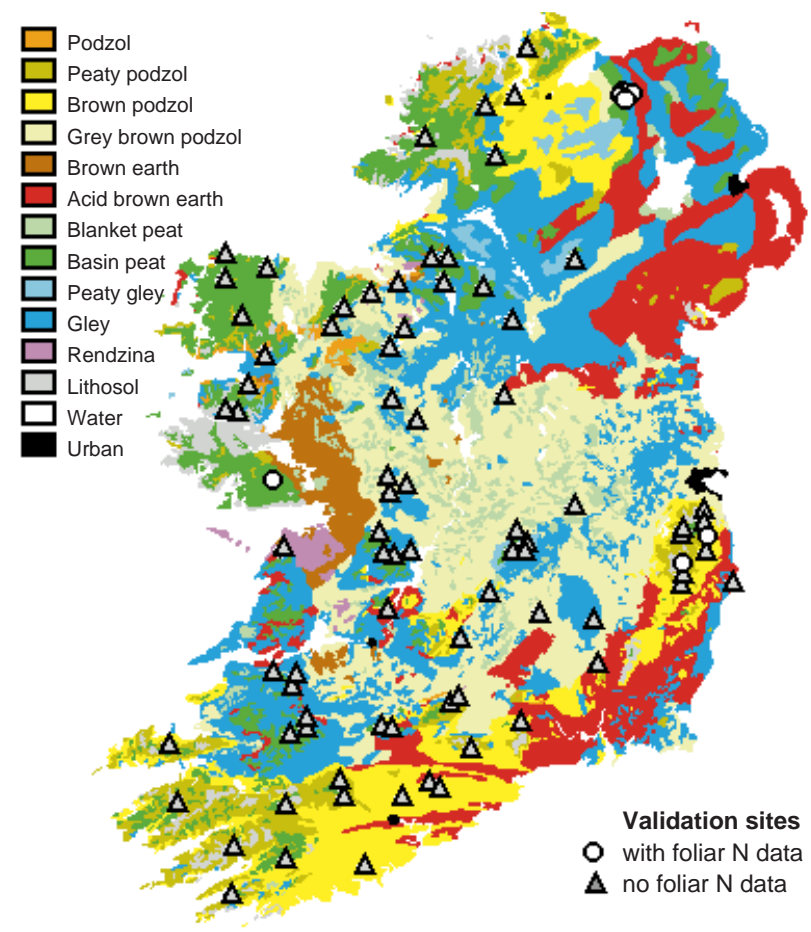

Fig. 3. Principal soils of Ireland used to map approximate soil water holding capacity (from Gardiner \& Radford 1980), with locations of stands used for validation 
Collins pers. comm.). For example, peatlands were assigned high $\mathrm{WHC}$ values $(16 \mathrm{~cm})$ while lithosols were assigned low values $(2 \mathrm{~cm})$. This approach enabled general characterizations of major differences in soil water, but was an approximation at best.

\subsection{Validation}

PnET-II's predictions of annual wood production $\left(\mathrm{m}^{3}\right.$ $\mathrm{ha}^{-1} \mathrm{yr}^{-1}$ ) were compared with estimates of yield class for 2 sets of stands: 7 stands from the literature with published foliar $\mathrm{N}$ values (Table 6), and 82 stands from the Irish Forestry Board (Coillte Teoranta) without foliar $\mathrm{N}$ data. For both sets of stands, elevations were estimated to within $30 \mathrm{~m}$ (100 feet) from 1:126720 ( $1 / 2$ inch : 1 mile) maps published by the Ordnance Survey of Ireland. Climate data were obtained from the climate models described above based on the latitude, longitude and elevation of each site (Goodale et al. 1998). WHC values were estimated from the stand's location within the GIS soil WHC data layer. For the 7 stand set, measured foliar $\mathrm{N}$ values were used, with one exception. Foliar N:P ratios at the Glenmalure site exceeded the critical 10:1 ratio, suggesting a phosphorus limitation. PnET-II was run for this site with both the measured foliar $\mathrm{N}$ concentration $(1.8 \%)$ and an 'effective' foliar $\mathrm{N}$ concentration of $1.2 \%, 10$ times the foliar $\mathrm{P}$ concentration. For the 82 stand set where foliar $\mathrm{N}$ data were not available, runs were performed using default values of $1.1 \%$ and $1.8 \%$ for all sites.

\subsection{Sensitivity analyses and predictions}

We used different sets of input parameters and a standardized set of site locations to assess the relative sensitivity of PnET-II predictions of N PP and wood production to predicted changes in climate and currently occurring variations in site quality. For each simulation presented below, PnET-II was run for the same subset of 830 locations randomly selected from a GIS for Ireland (Goodale et al. 1998). Soil WHC and elevation were determined for each site by location within the GIS, and the selected pixels had elevation and WHC distributions identical to those of the full GIS. Ambient climate conditions were determined for each pixel using regional climate models (Goodale et al. 1998). Sensitivity to climate change was determined by altering temperature and precipitation for each pixel as predicted by the Hadley Centre GCM. Sensitivity to site quality was determined by varying foliar $\mathrm{N}$ concentration across the range of values measured in Ireland (Table 3). Results were compared with predicted sensitivity to errors in parameter estimation and to the current range in ambient climate and site quality conditions.

Climate and $\mathrm{CO}_{2}$. An ambient control and 5 climate change scenarios were run for each of 3 different foliar $\mathrm{N}$ concentrations $(0.9,1.5$ and $2.1 \%)$. The first 4 climate change runs consisted of changes in individual parameters: symmetric and asymmetric temperature changes, precipitation changes, and the effects of $\mathrm{CO}_{2}$ enrichment on water use efficiency. A fifth run incorporated changes in temperature, precipitation and water use efficiency all at once. For the first temperature change run (symmetric temperature increases) both daily maximum and minimum temperature were increased by the same amount (Table 7) using seasonal sulfate-corrected predictions obtained from the Hadley Centre GCM (Mitchell et al. 1995, http://www.cru.uea.ac.uk/link/). In the second run (asymmetric temperature increases), changes in minimum temperature accounted for two-thirds of the

Table 6. Site descriptions of the 7 locations with published foliar $\mathrm{N}$ data. Age, elevation, foliar $\mathrm{N}$ and yield class were provided for all sites. The foliar $\mathrm{N}$ value in parentheses is an 'effective' foliar N value based on phosphorus limitation. WHC values were estimated from descriptions of soil type

\begin{tabular}{|c|c|c|c|c|c|c|}
\hline Site & $\begin{array}{c}\text { Age } \\
(y r)\end{array}$ & $\begin{array}{l}\text { Elevation } \\
(\mathrm{m})\end{array}$ & $\begin{array}{c}\text { Mean foliar } \\
\mathrm{N} \%\end{array}$ & $\begin{array}{c}\text { Est. WHC } \\
(\mathrm{cm})\end{array}$ & $\begin{array}{l}\text { Yield class } \\
\left(\mathrm{m}^{3} \mathrm{ha}^{-1} \mathrm{yr}^{-1}\right)\end{array}$ & $\begin{array}{c}\text { PnET-II } \\
\text { wood volume } \\
\text { increment } \\
\left(\mathrm{m}^{3} \mathrm{ha}^{-1} \mathrm{yr}^{-1}\right)\end{array}$ \\
\hline Cloosh $^{a}$ & 35 & 102 & 1.47 & 16 & 18 & 18 \\
\hline Roundwood $^{\mathrm{a}}$ & 38 & 395 & 1.76 & 10 & 16 & 17 \\
\hline Glenmalure $^{\mathrm{b}}$ & 33 & 350 & $1.80(1.21)$ & 14 & 14 & $21(10)$ \\
\hline Cam Forest $1^{\mathrm{C}}$ & 17 & 250 & 1.04 & 14 & $6-8$ & 7 \\
\hline Cam Forest $2^{\mathrm{C}}$ & 17 & 250 & 1.24 & 14 & 12 & 10 \\
\hline Cam Forest $3^{c}$ & 17 & 250 & 1.28 & 14 & $14-16$ & 10 \\
\hline Cam Forest $4^{\mathrm{C}}$ & 17 & 250 & 1.55 & 14 & 20 & 16 \\
\hline
\end{tabular}


Table 7. Climate change predictions used in tests of sensitivity of forest production. Values are from the Hadley Center GCM (Mitchell et al. 1995). Predictions are from a model experiment in which the effects of sulfate aerosols are combined with effects of increases in greenhouse gases. Winter is December, J anuary and February; spring is M arch, A pril and M ay; summer is J une, J uly and August; and fall is September, October and November. Distribution of temperature change between maximum and minimum assumes that $2 / 3$ of the change in mean temperature is due to increases in minimum temperature

\begin{tabular}{|lcccc|}
\hline \multirow{2}{*}{$\begin{array}{l}\text { Climate } \\
\text { parameter }\end{array}$} & Winter & Spring & Summer & Fall \\
\hline M ean temp. $\left({ }^{\circ} \mathrm{C}\right)$ & +2.1 & +1.8 & +2.1 & +2.3 \\
Max. temp. $\left({ }^{\circ} \mathrm{C}\right)$ & +1.1 & +0.9 & +1.1 & +1.2 \\
Min. temp. $\left({ }^{\circ} \mathrm{C}\right)$ & +3.2 & +2.7 & +3.2 & +3.5 \\
Precip. $\left(\mathrm{cm} \mathrm{mo} \mathrm{mo}^{-1}\right)$ & +0.6 & +0.6 & -0.3 & +0.6 \\
\hline
\end{tabular}

culated as the percent change in productivity (NPP or wood growth) divided by the percent change in the parameter value.

Ambient soil and climate. The effects of spatial variation in current climate and soil conditions on NPP or wood production are captured as variation around the mean for each of the runs performed.

\section{RESULTS AND DISCUSSION}

\subsection{Validation}

PnET-II's predictions agreed fairly well with published yield class estimates of production where foliar $\mathrm{N}$ data were available

change in mean temperature, while maximum temperatures were increased only slightly (Table 7). Both methods result in the same increase in monthly mean temperature, but have different effects on nighttime respiration and on VPD. In the third run, precipitation was altered seasonally according to the Hadley Center predictions in which precipitation increased in all seasons except summer, when it decreased (Table 7). These monthly changes were added to the monthly climate values for each of the 830 pixels in the subset of the Irish DEM used for these analyses.

In the fourth run, we simulated the physiological effects of $\mathrm{CO}_{2}$ enrichment by increasing water use efficiency only, as in previous applications of PnET-II (A ber et al. 1995). This may underestimate actual sensitivity to enrichment as potential increases in photosynthesis are ignored. Essentially, this assumes that nutrient limitations will lead to a down-regulation of photosynthesis, leaving only the water use efficiency effects in place (see discussion in Section 2 above).

The fifth climate change run combined the effects of changes in precipitation, temperature and $\mathrm{CO}_{2}$ enrichment. This run represents the prediction for the combined effects of the changes described here on forest production in Ireland across a range of site qualities.

Site quality. To determine sensitivity to site quality, summarized in these simulations as foliar $\mathrm{N}$ concentration, we varied foliar $\mathrm{N}$ from $0.9 \%$ to $2.1 \% \mathrm{~N}$ (Table 8) to capture most of the measured range in this parameter in Ireland and Scotland.

Potential errors in physiological parameters. In addition to foliar $\mathrm{N}$, each of the vegetation parameters discussed above was varied across the range of published values (Table 8), with the exception of DVPDA and DVPDB, FolReten, and PsnTM in for which the variation could not be assessed from the studies available. PsnTM in was varied $\pm 2^{\circ} \mathrm{C}$, and the other 3 parameters were varied $\pm 10 \%$. Sensitivity indices were cal-
(Fig. 4). Wood production estimates for 6 of the 7 sites fell within $5 \mathrm{~m}^{3} \mathrm{ha}^{-1} \mathrm{yr}^{-1}$ of the actual yield classes, which are generally reported in $2 \mathrm{~m}^{3} \mathrm{ha}^{-1} \mathrm{yr}^{-1}$ classes. The Glenmalure site was predicted more accurately with the 'effective' foliar $\mathrm{N}$ value equal to 10 times the phosphorus concentration, than by actual foliar $\mathrm{N}$. This suggests that nutrient limitation by elements other than nitrogen may be represented by 'effective' $\mathrm{N}$ concentrations based on critical $\mathrm{N}$ :element ratios. Additional data from sites with foliar $\mathrm{N}$ and $\mathrm{P}$ values would provide a more rigorous test of the model.

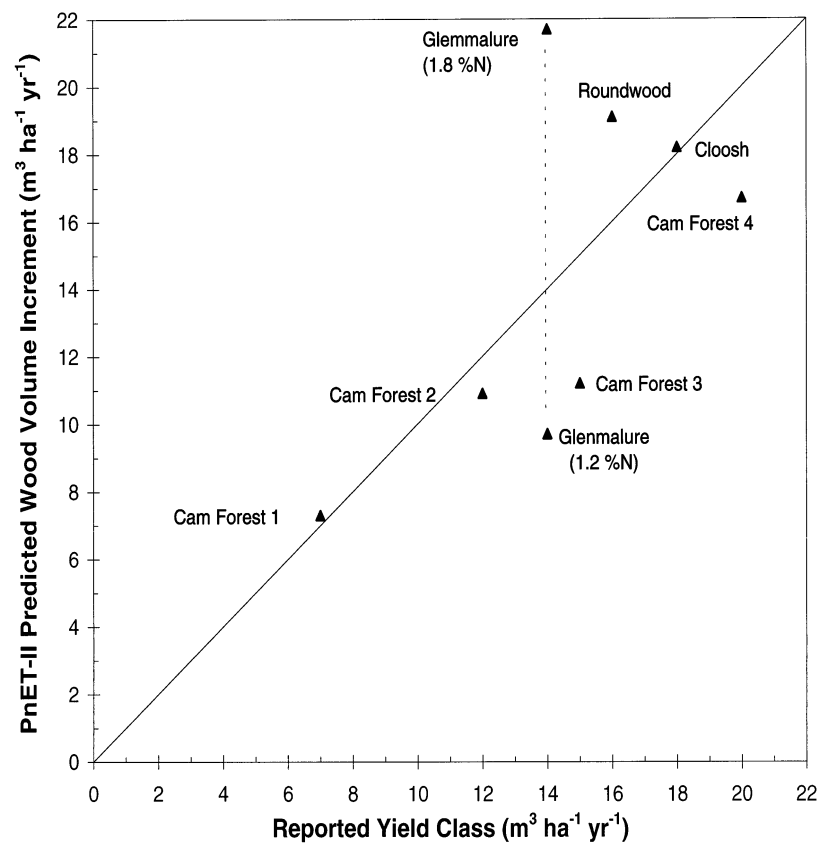

Fig. 4. PnET-II predictions of annual wood volume increment compared to yield class estimates at 7 sites with published foliar $\mathrm{N}$ and yield class data (Table 6) 
Yield class at the 82 Coillte Teoranta sites with no available foliar $\mathrm{N}$ data averaged $16.5 \mathrm{~m}^{3} \mathrm{ha}^{-1} \mathrm{yr}^{-1}$. PnET-II generally overpredicted mean wood production $\left(21.5 \mathrm{~m}^{3}\right.$ $\mathrm{ha}^{-1} \mathrm{yr}^{-1}$ ) when foliar $\mathrm{N}$ was set to $1.8 \%$ at all sites and underpredicted wood production $\left(8.8 \mathrm{~m}^{3}\right.$ $\mathrm{ha}^{-1} \mathrm{yr}^{-1}$ ) when $1.1 \%$ was used instead (Fig. 5). The differences between PnET-II and Coillte wood production estimates did not follow any discernible pattern with respect to elevation, age, estimated WHC, estimated soil type, calculated temperature, or calculated precipitation. The effect of wind in reducing potential Sitka spruce growth was estimated from empirical relations developed in Scotland (Worrell \& Malcolm 1990a, b) and an existing wind zonation map for Ireland (Miller 1986), but this index also failed to explain the discrepancy between Coillte Teoranta and PnET-II growth estimates. Based on the more successful results where foliar $\mathrm{N}$ values were known (Fig. 4) and the results of sensitivity analyses below, we believe that actual stand-level variation in foliar nitrogen status, were such data available, would explain much the observed variation in yield class.

Yield class is not a direct measurement of tree volume growth, but an index of a stand's predicted maximum mean annual growth rate $\left(\mathrm{m}^{3}\right.$ bolewood $\left.\mathrm{ha}^{-1} \mathrm{yr}^{-1}\right)$, generally expressed in increments of $2 \mathrm{~m}^{3} \mathrm{ha}^{-1} \mathrm{yr}^{-1}$. These empirical models have not been tested in Ireland, and their validity may not continue at sites experiencing environmental change (Bossel 1991, M ohren \& Burkhart 1994, Spiecker et al. 1996). Thus, errors may occur in either PnET-predicted or 'observed' yield class.

Wood growth is also one of the most difficult processes for the PnET model to predict accurately, in that the model allocates carbon to wood only after all other plant demands are met. As a residual term, wood production is the least constrained term in the stand carbon balance and is particularly sensitive to changes in the system's carbon economy.

\subsection{Sensitivity analyses}

The effects on NPP and wood production of either ambient variation in climate and soil WHC or predicted increases in temperature, precipitation and $\mathrm{CO}_{2}$ are quite small relative to the effects of ambient variability in site quality represented as changes in foliar $\mathrm{N}$ concentration (Fig. 6).

Climate and $\mathrm{CO}_{2}$. A mong climate change runs, predicted differences in NPP were always less than $9 \%$ (Fig. 6). This is less than the variability due to variation in ambient climate and soil conditions. Differences in wood production between climate change treatments were greater than differences in NPP as PnET-II gives allocation priority to foliage and roots, and lower priority to wood. Still, these differences never exceeded $30 \%$ and generally were less than $15 \%$. Differences were accentuated at higher foliar $\mathrm{N}$ concentrations. In general, those treatments which increased the length of the growing season (temperature increases) increased wood production. The asymmetric temperature increase resulted in an even longer growing season, and hence even more wood production, than the symmetric increase. The asymmetric temperature change also decreased VPD and so increased water use efficiency as described above. However, increased water use efficiency alone was only important at the highest foliar $\mathrm{N}$ level, where the higher rate of photosynthesis, and hence transpiration, resulted in a small amount of water stress. The combined effects of predicted increases in temperature, precipitation and $\mathrm{CO}_{2}$ are predicted to be minor for forests in Ireland (Fig. 6, 
Table 8. Mean sensitivity of model predictions of net primary production (NPP, $\mathrm{g} \mathrm{m}^{-2}$ ) and wood volume increment $\left(\mathrm{m}^{3}\right.$ ha-1) to changes in 12 vegetation parameters for 830 randomly-selected sites. Each parameter value was varied according to the range of published data values. The sensitivity index is the ratio of the percent change in model predictions to the percent change in the input parameter. OM: organic matter

\begin{tabular}{|c|c|c|c|c|c|c|}
\hline \multirow[t]{2}{*}{ Standard value } & \multicolumn{2}{|c|}{ Tested value } & \multicolumn{2}{|c|}{$\%$ Change } & \multicolumn{2}{|c|}{ Sensitivity index } \\
\hline & & & NPP & Yield class & NPP & Yield class \\
\hline & & & $\begin{array}{l}\text { Standard value: } \\
2101 \mathrm{~g} \mathrm{OM} \mathrm{m}^{-2}\end{array}$ & $\begin{array}{l}\text { Standard value: } \\
25 \mathrm{~m}^{3} \mathrm{ha}^{-1}\end{array}$ & & \\
\hline Foliar $\mathrm{N}=1.8$ & $\begin{array}{l}0.9 \\
1.2 \\
1.5 \\
2.1\end{array}$ & $\begin{array}{r}-50 \% \\
-33 \% \\
-17 \% \\
17 \%\end{array}$ & $\begin{array}{r}-47 \% \\
-28 \% \\
-12 \% \\
9 \%\end{array}$ & $\begin{array}{r}-67 \% \\
-45 \% \\
-20 \% \\
16 \%\end{array}$ & $\begin{array}{l}0.95 \\
0.83 \\
0.72 \\
0.57\end{array}$ & $\begin{array}{l}1.33 \\
1.34 \\
1.20 \\
0.97\end{array}$ \\
\hline$k=0.5$ & $\begin{array}{l}0.43 \\
0.57\end{array}$ & $\begin{array}{r}-14 \% \\
14 \%\end{array}$ & $\begin{array}{r}7 \% \\
-8 \%\end{array}$ & $\begin{array}{r}5 \% \\
-6 \%\end{array}$ & $\begin{array}{l}-0.53 \\
-0.54\end{array}$ & $\begin{array}{l}-0.35 \\
-0.44\end{array}$ \\
\hline SLWDel $=0.06$ & $\begin{array}{l}0.056 \\
0.063\end{array}$ & $\begin{array}{r}-7 \% \\
5 \%\end{array}$ & $\begin{array}{l}<0.1 \% \\
<0.1 \%\end{array}$ & $\begin{array}{l}<0.1 \% \\
<0.1 \%\end{array}$ & $\begin{array}{l}-0.04 \\
-0.03\end{array}$ & $\begin{array}{r}0.01 \\
-0.01\end{array}$ \\
\hline SLWMax $=275$ & $\begin{array}{l}260 \\
290\end{array}$ & $\begin{array}{r}-6 \% \\
6 \%\end{array}$ & $\begin{array}{r}-3 \% \\
3 \%\end{array}$ & $\begin{array}{r}-3 \% \\
2 \%\end{array}$ & $\begin{array}{l}0.61 \\
0.55\end{array}$ & $\begin{array}{l}0.48 \\
0.34\end{array}$ \\
\hline FolReten $=2.6$ & $\begin{array}{l}2.3 \\
2.9\end{array}$ & $\begin{array}{r}-12 \% \\
12 \%\end{array}$ & $\begin{array}{r}-3 \% \\
2 \%\end{array}$ & $\begin{array}{r}-11 \% \\
8 \%\end{array}$ & $\begin{array}{l}0.22 \\
0.16\end{array}$ & $\begin{array}{l}0.95 \\
0.72\end{array}$ \\
\hline GDDStart $=650$ & $\begin{array}{l}550 \\
750\end{array}$ & $\begin{array}{r}-15 \% \\
15 \%\end{array}$ & $\begin{array}{l}<0.1 \% \\
<0.1 \%\end{array}$ & $\begin{array}{r}1 \% \\
-1 \%\end{array}$ & $\begin{array}{l}-0.03 \\
-0.03\end{array}$ & $\begin{array}{l}-0.05 \\
-0.04\end{array}$ \\
\hline GDDEnd $=1500$ & $\begin{array}{l}1400 \\
1600\end{array}$ & $\begin{array}{r}-7 \% \\
7 \%\end{array}$ & $\begin{array}{r}<-0.1 \% \\
<0.1 \%\end{array}$ & $\begin{array}{r}<-0.1 \% \\
<0.1 \%\end{array}$ & $\begin{array}{l}<0.01 \\
<0.01\end{array}$ & $\begin{array}{l}<0.01 \\
<0.01\end{array}$ \\
\hline PsnTM in $=0$ & $\begin{array}{r}-2 \\
2\end{array}$ & & $\begin{array}{r}5 \% \\
-8 \%\end{array}$ & $\begin{array}{r}8 \% \\
-11 \%\end{array}$ & & \\
\hline PsnTOpt $=19$ & $\begin{array}{l}17 \\
21\end{array}$ & & $\begin{array}{l}-1 \% \\
<0.1 \%\end{array}$ & $\begin{array}{c}<0.1 \% \\
-2 \%\end{array}$ & & \\
\hline DVPDA $=0.19$ & $\begin{array}{l}0.19 \\
0.23\end{array}$ & $\begin{array}{r}-10 \% \\
10 \%\end{array}$ & $\begin{array}{r}2 \% \\
-1 \%\end{array}$ & $\begin{array}{r}2 \% \\
-2 \%\end{array}$ & $\begin{array}{l}-0.16 \\
-0.15\end{array}$ & $\begin{array}{l}-0.23 \\
-0.22\end{array}$ \\
\hline PreclntFrac $=0.33$ & $\begin{array}{l}0.22 \\
0.49\end{array}$ & $\begin{array}{r}-33 \% \\
48 \%\end{array}$ & $\begin{array}{r}2 \% \\
-6 \%\end{array}$ & $\begin{array}{r}3 \% \\
-7 \%\end{array}$ & $\begin{array}{l}-0.07 \\
-0.12\end{array}$ & $\begin{array}{l}-0.10 \\
-0.15\end{array}$ \\
\hline BoleFrac $=0.64$ & $\begin{array}{l}0.59 \\
0.69\end{array}$ & $\begin{array}{r}-8 \% \\
8 \%\end{array}$ & $\begin{array}{l}0 \% \\
0 \%\end{array}$ & $\begin{array}{r}-8 \% \\
8 \%\end{array}$ & $\begin{array}{l}0.00 \\
0.00\end{array}$ & $\begin{array}{l}1.00 \\
1.00\end{array}$ \\
\hline Density $=0.34$ & $\begin{array}{l}0.3 \\
0.4\end{array}$ & $\begin{array}{r}-12 \% \\
18 \%\end{array}$ & $\begin{array}{l}0 \% \\
0 \%\end{array}$ & $\begin{array}{r}-12 \% \\
18 \%\end{array}$ & $\begin{array}{l}0.00 \\
0.00\end{array}$ & $\begin{array}{l}1.00 \\
1.00\end{array}$ \\
\hline
\end{tabular}

rightmost bar in each group). Overall, changes in NPP or wood production induced by changing temperature, precipitation and water use efficiency separately or in combination were no more than $30 \%$ of ambient (control run) values, assuming no feedback between climate change and site fertility.

Changes in NPP and wood production are not always proportional in PnET-II. Conditions of water stress result in lower allocations to foliage in the following year and hence higher proportional allocation to wood. Thus the increase in NPP in the water use efficiency run at $2.1 \%$ foliar $\mathrm{N}$ relieves water stress, leading to higher allocations to foliage, with less of an effect on wood production.

Site quality. In contrast to the small changes predicted in response to climate change, a 2-fold increase in NPP and a 4-fold increase in wood production are predicted over the measured range of foliar $\mathrm{N}$ concen- trations values currently existing in the field (Fig. 6). The range of values for yield class predicted over the measured range of foliar $\mathrm{N}$ concentrations is in agreement with the range of measured yield class values for Ireland (Fig. 5).

Physiological parameters. A comparison of model sensitivity to foliar $\mathrm{N}$ and other physiological parameters also emphasizes the potential importance of site quality relative to potential errors in specification of these parameters (Table 8). Not only is the model extremely sensitive to small differences in foliar nitrogen (sensitivity indices of 1.0 or more), but Sitka spruce foliar $\mathrm{N}$ contents also vary widely from site to site (Table 3).

Following foliar nitrogen content, foliar retention time, maximum specific leaf weight, and the light attenuation constant were the next most critical model parameters, although production estimates changed 

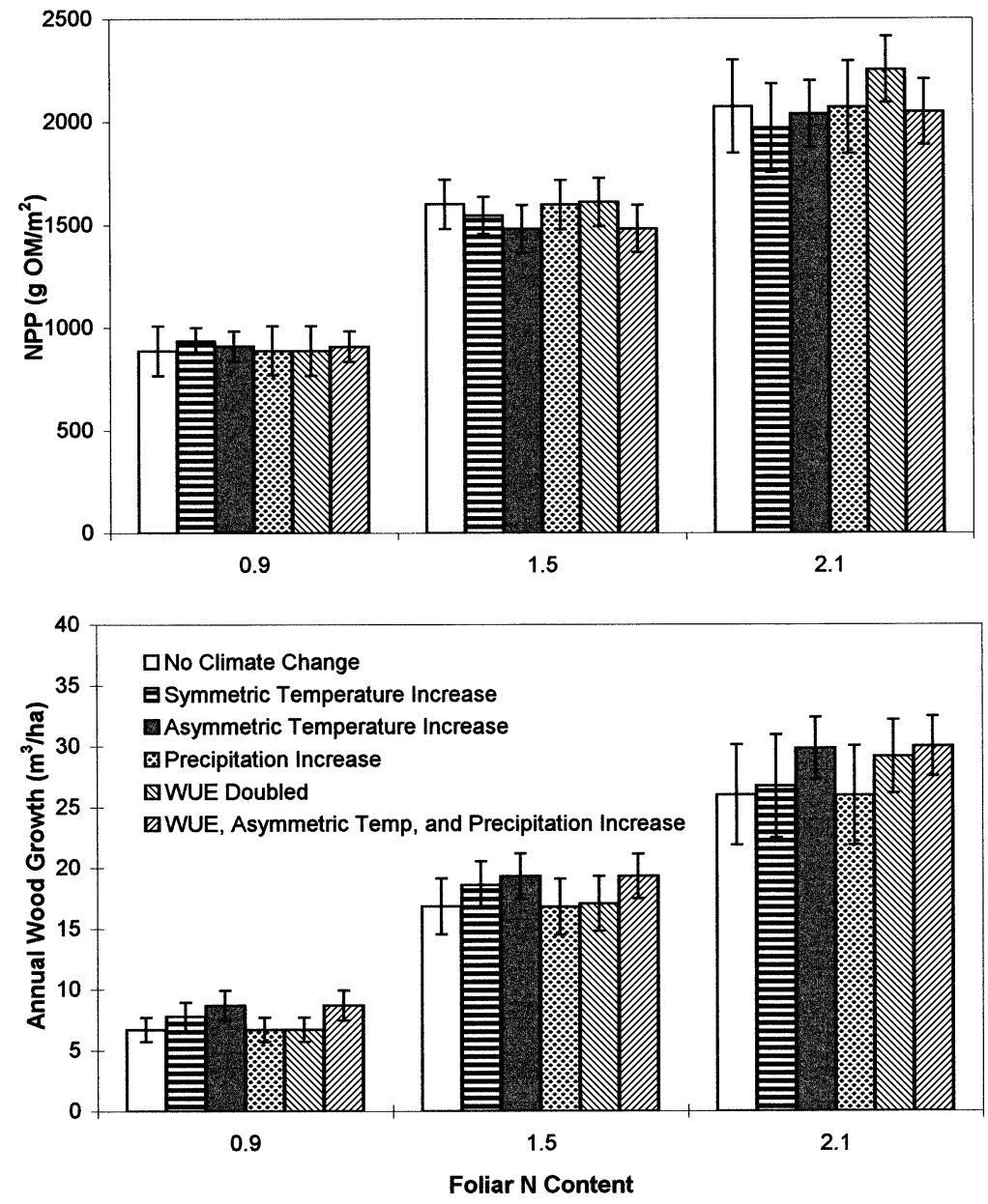

Fig. 6. PnET-II predictions of NPP (g organic matter $\mathrm{m}^{-2}$ ) and annual wood volume increment $\left(\mathrm{m}^{3} \mathrm{ha}^{-1}\right)$ under current and changed climates at 3 different levels of foliar nutrition. In the first climate change scenario, maximum and minimum temperatures were increased equally (symmetric temp. increase), and in the second, minimum temperatures were increased more than maximum (asymmetric temp. increase). See text for more complete description. Bars represent mean ( $\pm 1 \mathrm{SD}$ ) values for $8301-\mathrm{km}^{2}$ pixels randomly selected from the Irish GIS

by $11 \%$ or less due to observed variability in measurements of these parameters (Table 8). Decreasing foliar retention time decreases wood production more than overall NPP (Table 8), because faster leaf turnover demands additional carbon allocation to leaves. NPP remains high, but little carbon remains for wood production.

Changing the minimum temperature required for photosynthesis by $2^{\circ} \mathrm{C}$ affected production far more than changing the optimum temperature did. Lowering the critical minimum threshold for photosynthesis (PsnTM in) increased NPP and wood production by extending the growing season to the late fall and early spring. Variation in phenology parameters had very minor effects on production, confirming that the rough values determined for these parameter values were adequate under these circumstances.

Considering the wide range of interception values observed (Table 4), interception impacts on production were quite small. Precipitation intercepted by the canopy is assumed in the model to evaporate and not contribute to soil water storage. This result indicates that water availability did not generally limit forest production in PnET-II runs.

Variation of BoleFrac and Density values did not affect predictions of NPP, but they did affect estimates of wood volume increment. Varying either BoleFrac or Density caused direct, uniform changes in the predicted wood volume increment at all pixels. Errors in specifying these 2 parameters could consistently bias predictions by up to $20 \%$.

Ambient soil and climate. Standard deviations for each individual run average less than $10 \%$ of the mean (Fig. 6), and represent the variability resulting from variation in ambient soil WHC and climate conditions across Ireland. This source of variability is relatively minor due to Ireland's maritime climate.

\section{CONCLUSIONS}

Site-level foliar $\mathrm{N}$ concentration was the most sensitive parameter in this analysis of potential forest production in Ireland. Site-to-site variation in foliar chemistry may be due to natural differences in site fertility (Körner 1989, M artin \& A ber 1997) or plantation management practices (Farrell 1990a, b, Farrell \& Boyle 1990, Schaible \& Dickson 1990). We conclude that these sitespecific treatments, in combination with previous site history, result in a range of forest productivity that is much greater than any likely to be induced by climate change or $\mathrm{CO}_{2}$ enrichment. Eamus \& J arvis (1989) drew a similar conclusion.

This result has global implications. Many models of regional NPP fail to include any index of $\mathrm{N}$ availability or site quality. Many of those models that do consider site quality use single default values of $\mathrm{N}$ availability for whole ecosystem types or regions (e.g. McGuire et al. 1992, Aber et al. 1995, VEMAP Members 1995, although Parton et al. 1993 provide an exception), which may strongly over- or under-represent the productivity of a large region (e.g. Fig. 5) particularly 
where land use practices or forest management have induced differences in site quality. Additionally, these models use parameters from ecosystem study sites chosen to represent relatively undisturbed, mature or equilibrium conditions, or are calibrated to data sets developed at these sites. Direct effects of human management on site quality may impact forest productivity and carbon storage far more than the indirect effects resulting from an altered atmosphere, and so models must begin to incorporate the broad-scale effects of land management on forest productivity. This may be possible through the use of remote sensing of foliar chemistry (Matson et al. 1994, Martin \& Aber 1997) or the incorporation of disturbance history into existing biogeochemical models (A ber et al. 1997). If we are to predict the actual role of climate change in altering forest productivity and global biogeochemistry, we must consider site quality-its spatial variability, controlling factors, and response to management and pollution loading.

Acknowledgements. Mr Peter Dodd provided yield class data from Coillte Teoranta. Dr J im Collins of the Department of Crop Science, Horticulture, and Forestry at the University College Dublin (UCD) provided soil water estimates for the soils of Ireland, and J ulian Aherne of the Forest Ecosystem Research Group at UCD assisted with digitizing. Drs C. A. Federer, R. Congalton, and several anonymous reviewers provided constructive comments on drafts of this manuscript. Research for this paper was from a thesis submitted to the Graduate School at the University of N ew Hampshire as part of the requirements for completion of a Master of Science degree. Financial support was provided by the U.S. EPA and the National Science Foundation's International and Longterm Ecological Research Programs.

\section{LITERATURE CITED}

Aber JD, Federer CA (1992) A generalized, lumped-parameter model of photosynthesis, evapotranspiration and net primary production in temperate and boreal forest ecosystems. Oecologia 92:463-474

Aber J D, Ollinger SV, Driscoll C (1997) Modeling nitrogen saturation in forest ecosystems in response to land use and atmospheric deposition. Ecol Model 101:61-78

Aber J D, Ollinger SV, Federer CA, Kicklighter DW, Melillo J M , Lathrop RGJ , Ellis J M (1995) Predicting the effects of climate change on water yield and forest production in the northeastern U.S. Clim Res 5:207-222

Aber J D, Reich PB, Goulden ML (1996) Extrapolating leaf $\mathrm{CO}_{2}$ exchange to the canopy: a generalized model of forest photosynthesis validated by Eddy correlation. Oecologia 106:257-265

Anderson AR, Pyatt DG (1986) Interception of precipitation by pole-stage Sitka spruce and Lodgepole pine and mature Sitka spruce at Kielder Forest, Northumberland. Forestry 59:29-38

Anonymous (1994) Pathway to progress: a programme for forest research \& development. National Council for Forest Research and Development, University College Dublin, Dublin
Bazzaz FA (1990) The response of natural ecosystems to the rising global $\mathrm{CO}_{2}$ levels. Annu Rev Ecol Syst 21:167-196

Bossel H (1991) Modelling forest dynamics: moving from description to explanation. For Ecol Manage 42:129-142

Brooks JR, Hinckley TM, Sprugel DG (1994) Acclimation responses of mature Abies amabilis sun foliage to shading. Oecologia 100:316-324

Cannell MGR, Sheppard LJ, Ford ED, Wilson RHF (1983) Clonal differences in dry matter distribution, wood specific gravity and foliage 'efficiency' in Picea sitchensis and Pinus contorta. Silvae Genet 32:195-202

Cannell MGR, Smith RI (1983) Thermal time, chill days and prediction of budburst in Picea sitchensis. J Appl Ecol 20: 951-963

Cannell MGR, Willett SC (1975) Rates and times at which needles are initiated in buds on differing provenances of Pinus contorta and Picea sitchensis in Scotland. Can J For Res 5:367-380

Carbonnier L (1991) Ireland-forestry; the potential. In: M olIan C, Maloney M (eds) The right trees in the right places: The proceedings of a conference on forestry and the environment held at the Royal Dublin Society on October 17-19, 1990. Royal Dublin Society, Dublin, p 48-55

Carey ML, O'Brien D (1979) Biomass, nutrient content and distribution in a stand of Sitka spruce. Ir For 36:25-35

Conway A (1991) Ireland-agriculture; the prospects. In: Mollan C, Maloney $M$ (eds) The right trees in the right places: The proceedings of a conference on forestry and the environment held at the Royal Dublin Society on October 17-19, 1990. Royal Dublin Society, Dublin, p 42-47

Curtis PD, Drake BG, Leadley PW, Arp W, Whigham DF (1989a) Growth and senescence of plant communities exposed to elevated $\mathrm{CO}_{2}$ concentrations on an estuarine marsh. Oecologia 78:20-26

Curtis PD, Drake BG, Whigham DF (1989b) Nitrogen and carbon dymanics in $\mathrm{C}_{3}$ and $\mathrm{C}_{4}$ estuarine marsh plants grown under elevated $\mathrm{CO}_{2}$ in situ. Oecologia 78:297-301

Dewar RC, Cannell M GR (1992) Carbon sequestration in the trees, products and soils of forest plantations; an analysis using UK examples. Tree Physiol 11:49-71

Eamus D, J arvis PG (1989) The direct effects of increase in the global atmospheric $\mathrm{CO}_{2}$ concentration on natural and commercial temperate trees and forests. In: Cragg J B (ed) Advances in ecological research. Academic Press, London, p 1-55

Edwards PN, Christie J M (1981) Yield models for forest management. Forestry Commission Booklet No. 48. HMSO, London

Farrell EP (1985) Long-term study of Sitka spruce (Picea sitchensis (Bong.) Carr.) on blanket peat. 2. Water-table depth, peat depth and nutrient mineralisation studies. Ir For 42:92-105

Farrell EP (1990a) Aspects of the nitrogen cycle in peatland and plantation forest ecosystems in western Ireland. Plant Soil 128:13-20

Farrell EP (1990b) Peatland forestry in the Republic of Ireland. In: Hanell B (ed) Proceedings of Biomass Production and Element Fluxes in Forested Peatland Ecosystems. Swedish University of Agricultural Sciences, Dept of Forest Site Research, UImea

Farrell EP, Boyle G (1990) Peatland and forestry in the 1990's. Ir For 47:69-78

Farrell EP, Cummins T, Boyle GM (1994) Intensive monitoring of forest ecosystems in Ireland. Final report. Forest Ecosystem Research Group Report Number 13. Department of Environmental Resource M anagement, University College Dublin 
Field C, M ooney HA (1986) The photosynthesis-nitrogen relationship in wild plants. In: Givinsh TJ (ed) On the economy of plant form and function. Cambridge University Press, New York, p 25-55

Ford ED (1982) High productivity in a polestage Sitka spruce stand and its relation to canopy structure. Forestry 55(1):1-17

Ford ED, Deans J D (1978) The effects of canopy structure on stemflow, throughfall and interception loss in a young Sitka spruce plantation. J Appl Ecol 15:905-917

Ford ED, Deans J D, Milne R (1987) Shoot extension in Picea sitchensis. I. Seasonal variation within a forest canopy. Ann Bot 60:531-542

Galloway J N, Schlesinger WH, Levy H II, Michaels A, Schnoor JL (1995) Nitrogen fixation: anthropogenic enhancement-environmental response. Global Biogeochem Cycles 9:235-252

Gardiner MJ, Radford T (1980) Ireland general soil map. National Soil Survey, An Foras Taluntais, Dublin

Gholz HL (1982) Environmental limits on aboveground net primary production, leaf area, and biomass in vegetation zones of the Pacific N orthwest. Ecology 63:469-481

Giorgi F, Marinucci MR, Visconti G (1992) A $2 \times \mathrm{CO}_{2}$ climate change scenario over Europe generated using a limited area model nested in a general circulation model. 2. Climate change scenario. J Geophys Res 97:10011-10028

Goodale CL, Aber J D, Ollinger SV (1998) Mapping monthly precipitation, temperature, and solar radiation for Ireland with polynomial regression and a digital elevation model. Clim Res 10:35-49

Grier CC, Logan RS (1977) Old-growth Pseudotsuga menziesii communities of a western Oregon watershed: biomass distribution and production budgets. Ecol Monogr 47:373-400

Grier CC, Vogt KA, Keyes MR, Edmonds RL (1981) Biomass distribution and above- and below-ground production in young and mature Abies amabilis zone ecosystems of the Washington Cascades. Can J For Res 11:155-167

Hamilton GJ (1985) Forest mensuration handbook. Forestry Commission Booklet No. 35. HMSO, London

Harcombe PA, Harmon ME, Greene SE (1990) Changes in biomass and production over 53 years in a coastal Picea sitchensis - Tsuga heterophylla forest approaching maturity. Can J For Res 20:1602-1610

Hom J L, Oechel WC (1983) The photosynthetic capacity, nutrient content, and nutrient use efficiency of different needle age-classes of black spruce (Picea mariana) found in interior Alaska. Can J For Res 13:834-839

Hudson J A (1988) The contribution of soil moisture storage to the water balance of upland forested and grassland catchments. Hydrol Sci J 22:1602-1616

J arvis PG (1981) Production efficiency of coniferous forest in the UK. In: J ohnson CB (ed) Physiological processes limiting plant productivity. Butterworths, London, $p$ 81-107

J arvis PG, J ames GB, Landsberg JJ (1976) Coniferous forest. In: M onteith J L (ed) Vegetation and the atmosphere. Academic Press, London, p 171-240

Jarvis PG, Leverenz JW (1983) Productivity of temperate, deciduous and evergreen forests. In: Lange OL, Osmond CB, Ziegler $\mathrm{H}$ (eds) Physiological plant ecology. IV. Springer-Verlag, New York, p 234-280

J ohnson RC (1990) The interception, throughfall and stemflow in a forest in Highland Scotland and the comparison with other upland forests in the U.K.J Hydrol 118:281-287

Kattenberg A, Giorgi F, Grassl H, Meehl GA, Mitchell J FB, Stouffer RJ, Tokioka T, Weaver AJ, Wigley TML (1996) Climate models-projections of future climate. In:
Houghton JT, Meira Filho LG, Callander BA, Harris N, Kattenberg A, Maskell K (eds) Climate change 1995: the science of climate change. Cambridge University Press, Cambridge

Kearney B (1994) Agriculture, forestry, and the environment in the year 2025. In: M ollan C, Maloney M (eds) The right trees in the right places. The proceedings of a conference on forestry and the environment held at the Royal Dublin Society on October 17-19. Royal Dublin Society, Dublin, p 56-63

Körner C (1989) The nutritional status of plants from high altitudes. Oecologia 81:379-391

Ludlow M M, J arvis PG (1971) Photosynthesis in Sitka spruce (Picea sitchensis (Bong.) Carr.) I. General characteristics. J Appl Ecol 12:879-892

Marinucci M R, Giorgi F (1992) A $2 \times \mathrm{CO}_{2}$ climate change scenario over Europe generated using a limited area model nested in a general circulation model. 1. Present day seasonal climate simulation. J Geophys Res 97:9989-10009

Martin ME, Aber JD (1997) High spectral resolution remote sensing of forest canopy lignin, nitrogen, and ecosystem processes. Ecol Appl 7:431-443

Matson P, J ohnson L, Billow C, M iller J , Pu R (1994) Seasonal patterns and remote spectral estimation of canopy chemistry across the Oregon transect. Ecol A ppl 4:280-298

McCarthy R (1993) Monitoring forest condition in Ireland. Ir For 50:21-34

M cEvoy T (1954) A review of Irish forestry. Ir For 11:20-27

M cEvoy T (1958) Forestry in Ireland. Adv Sci 56:307-316

McGuire AD, Melillo J M, J oyce LA, Kicklighter DW, Grace AL, Moore B III (1992) Interactions between carbon and nitrogen dynamics in estimating net primary productivity for potential vegetation in North America. Global Biogeochem Cycles 6:101-124

McMurtrie RE, Leuning $R$, Thompson WA, Wheeler AM (1992) A model of canopy photosynthesis and water use incorporating a mechanistic formulation of leaf $\mathrm{CO}_{2}$ exchange. For Ecol M anage 52:261-278

Miller HG, Miller J D (1976) Effect of nitrogen supply on net primary production in Corsican pine. J Appl Ecol 13: 249-256

Miller JD, Cooper J M, Miller HG (1993) A comparison of above-ground component weights and element amounts in four forest species at Kirkton Glen. J Hydrol 145: 419-438

Miller KF (1986) Windthrow hazard in conifer plantations. Ir For 43:66-78

Mitchell AK, Hinckley TM (1993) Effects of foliar nitrogen concentration on photosynthesis and water use efficiency in Douglas-fir. Tree Physiol 12:403-410

Mitchell KFB, J ohns TC, Gregory J M, Tett ASFB (1995) Climate response to increasing levels of greenhouse gases and sulphate aerosols. N ature 376:501-504

Mohren GMJ , Burkhart HE (1994) Contrasts between biologically-based process models and management-oriented growth and yield models. For Ecol Manage 69:1-5

Neilson RE, Ludlow M M, J arvis PG (1972) Photosynthesis in Sitka spruce (Picea sitchensis (Bong.) Carr.) II. Response to temperature. J Appl Ecol 9:721-745

Nicholls N, Gruza GV, J ouzel J, Karl TR, Ogallo LA, Parker DE (1996) Observed climate variability and change. In: Houghton JT, Meira Filho LG, Callander BA, Harris N, Kattenberg A, Maskell K (eds) Climate change 1995: the science of climate change. Cambridge University Press, Cambridge, p 132-192

Norman J M, J arvis PG (1972) Photosynthesis in Sitka spruce (Picea sitchensis (Bong.) Carr.) III. Measurements of 
canopy structure and interception of radiation. J Appl Ecol 9:375-398

Oberbauer SF, Sionit N, Hastings SJ, Oechel WC (1986) Effects of $\mathrm{CO}_{2}$ enrichment and nutrition on growth, photosynthesis, and nutrient concentration of Alaskan tundra plant species. Can J Bot 64:2993-2999

Parton, WJ , Scurlock J MO, Ojima DS, Gilmanov TG, Scholes RJ , Schimel DS, Kirchner T, Menaut J C, Seastedt T, Garcia M oya E, Kamnalrut A, Kinyamario J I (1993) Observations and modeling of biomass and soil organic matter dynamics for the grassland biome worldwide. Global Biogeochem Cycles 7:785-809

Pastor J, Post WM (1986) Influence of climate, soil moisture, and succession on forest carbon and nitrogen cycles. Biogeochemistry 2:3-27

Pierce LL, Running SW (1988) Rapid estimation of coniferous forest leaf area index using a portable integrating radiometer. Ecology 69:1762-1767

Pierce LL, Running SW, Walker J (1994) Regional-scale relationships of leaf area index to specific leaf area and nitrogen content. Ecol Appl 4:313-321

Pitelka LF (1994) Ecosystem response to elevated $\mathrm{CO}_{2}$. TREE 9:201-239

Polley HW, Johnson HB, Marino BD, Mayeux HS (1993) Increase in $\mathrm{C}_{3}$ plant water-use efficiency and biomass over Glacial to present $\mathrm{CO}_{2}$ concentrations. Nature 361:61-64

Raich J W, Rastetter EB, M elillo J M, Kicklighter DW, Steudler PA, Peterson BJ , Grace AL, Moore B III, Vorosmarty CJ (1991) Potential net primary productivity in South America: application of a global model. Ecol Appl 1:339-429

Reich PB, Kloeppel B, Ellsworth DS, Walters M B (1995) Different photosynthesis-nitrogen relations in deciduous hardwood and evergreen coniferous tree species. Oecologia 104:24-30

Reich PB, Schoettle AW (1988) Role of phosphorus and nitrogen in photosynthetic and whole plant carbon gain and nutrient use efficiency in eastern white pine. Oecologia 77:25-33

Reich PB, Walters MB, Ellsworth DS, Uhl C (1994) Photosynthesis-nitrogen relations in Amazonian tree species. I. Patterns among species and communities. Oecologia 97:62-72

Running SW (1976) Environmental control of leaf water conductance in conifers. Can J For Res 6:104-112

Running SW, Coughlan J C (1988) A general model of forest ecosystem processes for regional applications. I. Hydrologic balance, canopy gas exchange and primary production processes. Ecol Model 42:125-154

Editorial responsibility: Brent Yarnal, University Park, Pennsylvania, USA
Sandford AP, J arvis PG (1986) Stomatal responses to humidity in selected conifers. Tree Physiol 2:89-103

Schaible R, Dickson DA (1990) Effects of drainage intensity and planting position on the growth and nutrition of second rotation Sitka spruce on shallow peat. Ir For 47:19-27

Spiecker H, Mielikainen K, Kohl M, Skovsgaard G (1996) Growth trends in European forests. Springer-Verlag, Heidelberg

Teklehaimanot Z, J arvis PG, Ledger D (1991) Rainfall interception and boundary layer conductance in relation to tree spacing. J Hydrol 123:261-278

Townend J (1993) Effects of elevated carbon dioxide and drought on the growth and physiology of clonal Sitka spruce plants (Picea sitchensis (Bong.) Carr.). Tree Physiol 13:389-399

Trenberth KE, Houghton JT, Meira Filho LG (1996) The climate system: an overview. In: Houghton JT, Meira Filho LG, Callander BA, Harris N, Kattenberg A, Maskell K (eds) Climate change 1995: the science of climate change. Cambridge University Press, Cambridge

VEMAP Members (1995) Vegetation/ecosystem modeling and analysis project: comparing biogeography and biogeochemistry models in a continental-scale study of terrestrial ecosystem responses to climate change and $\mathrm{CO}_{2}$ doubling. Global Biogeochem Cycles 9:407-737

Vitousek PM (1994) Beyond global warming: ecology and global change. Ecology 75:1861-1876

Waring RH, Franklin J F (1979) Evergreen coniferous forests of the Pacific N orthwest. Science 204:1380-1386

Watts WR, Neilson RE (1978) Photosynthesis in Sitka spruce (Picea sitchensis (Bong.) Carr.) VIII. Measurements of stomatal conductance and ${ }^{14} \mathrm{CO}_{2}$ uptake in controlled environments. J Appl Ecol 15:245-255

Watts WR, Neilson RE, Jarvis PG (1976) Photosynthesis in Sitka spruce (Picea sitchensis (Bong.) Carr.) VII. M easurements of stomatal conductance and ${ }^{14} \mathrm{CO}_{2}$ uptake in a forest canopy. J Appl Ecol 13:623-638

Woodward FI, Thompson GB, M cKee IF (1991) The effects of elevated concentrations of carbon dioxide on individual plants, populations, communities, and ecosystems. Ann Bot 67:23-38

Worrell R, Malcolm DC (1990a) Productivity of Sitka spruce in northern Britain. 1. The effects of elevation and climate. Forestry 63:105-118

Worrell R, M alcolm DC (1990b) Productivity of Sitka spruce in northern Britain. 2. Prediction from site factors. Forestry 63:419-428

Submitted: September 10, 1996; Accepted: November 3, 1997 Proofs received from author(s): M arch 30, 1998 